\title{
Russia in Search of National Integration Model
}

\author{
Anatoly Vladimirovich Lubsky ${ }^{1}$ \\ Alina Gavrilovna Lurje² \\ Alexander Vasilievich Popov ${ }^{3}$ \\ Irina Borisovna Serikova ${ }^{4}$ \\ Dmitry Sergeevich Zagutin ${ }^{5}$

\begin{abstract}
${ }^{1}$ Southern Federal University, Rostov-on-Don, Russian Federation
2Southern Federal University, Rostov-on-Don, Russian Federation

${ }^{3}$ Southern Federal University, Rostov-on-Don, Russian Federation

${ }^{4}$ Southern Federal University, Rostov-on-Don, Russian Federation

${ }^{5}$ Rostov State University of Economics (RINE), Rostov-on-Don, Russian Federation
\end{abstract}

Email:n_lav@mail.ru

Doi:10.5901/mjss.2015.v6n4s4p209

\begin{abstract}
National identity is an important factor in the social consolidation of the society as a prerequisite for national integration. In this regard, the article attempts to find the all-Russian identity, being able to overcome the disintegrative potential of ethnic and ethno-confessional diversity in the Russian society. National and civilizational identity, formed on the basis of an image of Russia as a local civilization can become such identity. The difficulties in the formation of the national and civilizational identity as one of the models of national integration are determined, on the one hand, by the presence of the different civilizational images of Russia in the discourse, and on the other hand, by the fact that the civilizational identity matrix is currently on the periphery of the mass consciousness in the Russian society, therefore socio-cultural and institutional practices acquire a special role in its construction.
\end{abstract}

Keywords: national integrity, identity, national identity, all-Russian identity, civilizational identity, ethno-confessional diversity, national security.

\section{Introduction}

In the era of late Art Nouveau a new configuration of "the world wholeness", in which the two interrelated trends are apparently expressed - globalization and localization, which were called glocalization (Robertson, 1995). In the context of these trends, globalization, catching itself in the formation of a single economic and informational space, poses a serious challenge to national differences (Huntington, 2004; Goldschmidt, 2010) and is accompanied by a crisis of national identities. Localization manifests itself in various communities' pursuit to strengthen their sense of autarchy, exclusivity and self-sufficiency, in seeking ways of national development, according to which the states seek to reconstruct the national identities (Robertson \& Knondker, 1999) which ensure national integration.

After the Soviet Union collapse and the loss of Soviet (Imperial) identity, Russia as a multiethnic community faced the problem of formation of a new national identity as the basis for national integration. In the 90-ies of the last century, the reformers' efforts in Russia were aimed at changing the vector of Russian society development in "catch-up" development style, in a liberal direction. In practice, however, the attempt to implement the linear model of liberal modernization failed. The Russian society returned to the state-centered matrix of development and refused the liberal modernization model, which was named the innovational-democratic one.

As a result, the Russian State started to resemble "the Knight at the crossroads", concerned, on the one hand, with the problems of entering the globalizing world space, and on the other hand, with the search for national development and national integration. Currently, the main form of national integration in Russia is a mobilization nation consolidation ("the Great imitators..."), which is guaranteed by the formation of national identity, in particular.

In the Russian society, composed of many ethnic groups, each of which has its own cultural and religious 
specificity, the task of forming the integrating national identity is especially difficult. Its solution is hampered by the fact that in scientific discourses, there are different, sometimes opposing, answers to the challenges thrown by the globalization to the national identity. In addition, in Russia, the problem of social cohesion as a factor of national integration is more important than in many developed countries. This is due to the presence of deep social inequalities, different social interests and value orientations in the Russian society.

\section{Literature Review}

The scientific literature already dealt with some aspects of discourses about integrating national identity in Russia. At this, the researchers note that the construction of the national identity, able to integrate the Russian society into a whole, was plagued by many problems from the start. Firstly, the matter was a forming of a substantially "new" Russian identity. Secondly, there appeared the uncertainty regarding the constructed community borders (both politico-geographical and cultural-symbolic). Thirdly, the ideological splits hindered the political self-determination of the Russian society. Fourthly, in the changing international and internal political context, the definition of "significant others", in relation to whom it was necessary to construct a new identity, also became an object for disagreements. Fifthly, the legacy of the long-time tradition of identity constructing according to mixed patterns was preserved: it's when both the desire to adapt the idea of nation to the Russian context and the temptation to imagine oneself "something else" took place (Malinova, 2010). Many discourse participants believe that in post-Soviet Russia there is no purposeful and meaningful public policy on the national identity. However, some of them still believe that there is such a policy, but it is contradictory, because the political elite prefers to pragmatically balance between the ideas of nation and civilization, while the proposed models of national identity are attempts to specifically combine civilizational and national matrix (Zevelev, 2009). civil identity.

Some of participants of discourse on national identity in Russia suggest distinguishing a public-civil and nationally

At this, they point out that public-civil identity is based on the etatist consciousness of individuals, which means, first and foremost, loyalty to the State. The basis of national civil identity is the civic consciousness, which primarily involves individual identification with the civil society as a civil nation. In the Western European tradition, public civil and national civic identities at some point became a match.

In the Russian tradition, the notions of state and civil consciousness do not match, therefore a civil identity means belonging to the state (Drobizheva, 2012).

In general, it should be noted that the issue of integrating national identity formation in Russia is currently being discussed and often demonstrating an ideologically coloured nature. As for the question of the search for a model of national integration in modern Russia, it has not yet been the subject of specific research.

\section{Methodology}

One can distinguish five semantic aspects in discursive practices, in which the term "identity" is used, that complementing each other, let one view it from different angles: 1) the phenomenon of collective self, 2) aspect of individuality, 3) the result of social interactions, 3) basis of social action, 5) the product of competing discourses (Brubaker \& Cooper, 2000). While an individual identity is understood as "one of the aspects of the individual's interpretation of social reality, namely that aspect, which relates to the structure and configuration of the individual's self in relation to social reality" (Greenfeld \& Eastwood, 2007).

In this connection, the individual identity has two levels-personal and social. The personal level is a set of personal characteristics that make the individual unique. The social level is linked with the individual's identification with his social roles and certain social groups (Karolewski, 2010).

From the methodological point of view, a distinction should be made between social and collective identities (Barkov, Lubsky \& Lubsky, 2013). Social identities are the result of individuals' self-identifying with specific reference groups, while collective identities are the result of matching individuals with "Us" as imagined communities.

In discourse practices, the notion of "imagined community" appeared thanks to B. Anderson, who believed that unlike the society as a place of direct communication, an imagined community is a mental image of the its people's collectivity (Anderson, 1983). It should be emphasized that the context of the collective imaginations is culture, while the source of it is collective memory and various discursive practices. In this regard, researchers distinguish between collective memories arising from a common cultural experience, and discourse areas, in which myths that underlie those or other collective identities are constantly generated, discussed and reconstructed (Bell 2003).

It is now possible to name "hard" and "soft" concepts of collective identities. The "hard" concepts developed within 
the framework of the essentialist approach to their study, based on the notion that the collective identities are set "naturally". The "soft" concepts of collective identities emerged within the constructivist approach to their interpretation. Thanks to the constructivists, the scientific discourse approved the notion that the collective identities are not natural and immutable entities, but something moving and multiple, dependent on the context.

It is now becoming clear that essentialist and constructivist interpretations of collective identities are methodologically unilateral. New features of their study are disclosed in line with such new areas as constructive realism within which collective identities are simultaneously interpreted as "natural" (cultural), the only sustainable and as "artificial" (constructed), multiple and volatile. It should be noted, however, that the "natural" identities are unconscious, they are formed in the process of cultural socialization, while "artificial" identities are deliberate, they arise from choosing imaginary referents.

That's why, collective identities, on the one hand, are formed with thee socially significant information, on the other hand, are determined by the cultural actualization. Such an approach to the study of collective identities manifests the desire, firstly, to show that they are not eternally specified, existing, apart from those constituting a specific team of individuals, and thus to avoid radical essentializing of collective identities, secondly, to overcome their purely constructivist understanding, because the identities are given not only the "artificial" but also the cultural dimension.

\section{Results}

The national identity is an important factor in social cohesion as a prerequisite for national integration. Interpretation of national identities as discourse constructors has entailed the conclusion about those identities' mobility, because they are the result of a symbolic struggle or competition between different narratives. At this, the researchers emphasize that there are usually several narratives about identities coexisting in the discourse, competing with each other, and people can make a choice among them (Martin, 1995). As a result, some narratives of identity may appear predominant, whereas others will be pushed by the wayside, however, the victory of one of collective identities can never be considered final (Roniger \& Sznajder, 1998).

Thus, national identities are formed as a result not only of the constructivist efforts (informational influence), but also of the cultural predispositions (unconscious) and also of the social readiness (deliberate) of individuals to perceive the images and representations of imagined communities as the basis for those identities. This is explained by the presence of various national identities in the society and, accordingly, of different national integration models.

Search for national integration models in Russia are closely connected to the discourse concepts of what is the Russian nation as a consolidated community. At this the discourse participants often use the language of Western intellectual tradition, which is the product of a particular cultural and historical development, and which was designed to examine another social reality. Here we don't talk about the situation, when one cannot use theoretical constructs developed within the Western intellectual tradition while examining the Russian nation. Here we talk about the necessity for their cognitive capacity to be weighed against the Russian socio-cultural specificity. In this connection, the discourse on the nation it is necessary to adhere to the principle of its contextuality, which suggests dealing with social phenomena within their natural cultural and historical environment.

In the discourse about the nation, one can distinguish multiple approaches to its understanding. One of them was formed under the influence of Old World thinkers and of "nation-building" practices in theWestern Europe. Under this approach a nation is seen as a community of people connected by the ethnic origin, language, religion, traditions, unity of economic interests and a single political system. At this, in the interpretation of nation one can pick out the German tradition, related to its understanding as an ethno-nation, and the French tradition in which the nation is seen as a political or civic nation.

Another approach is associated with the ideas and practice of "nation-building" in the United States, which identifies the concepts of nation and State, and bases the ideas of nation not on the ethnical commonness or shared history, but on loyalty to the country and commitment to freedom and democracy. This makes America, as the researchers note, loyal to its domestic "others" and disloyal to external "others", allowing Americans to consider those, who reject American values, anti-Americans. Scientists therefore believe that in the Western European sense of the word, the American nation today doesn't exist, like previously the Soviet nation didn't exist, so Americans are not a nation, but people (Inozemtsev, 2013). In our opinion, the American people should be classified as an ideological nation (along with, for example, the multinational Soviet people) based on ideological values and the idea of national exclusiveness.

In General, you can distinguish several historically formed variants of nations' origin. Firstly, this is a mono-ethnic nation formation based on the commonness of ethnic origin, religion, language, economic interests and the unity of the political system (nation-state). Based on this nation a national-ethnic identity is formed. Secondly, the formation of a 
multiethnic nation on the basis of common state (national) interests and values (a political nation). On the basis of this nation, a national-state identity is formed. Thirdly, there is the formation of a multiethnic nation based on the civil society (a civil nation). On the basis of this nation, the national civic identity is formed. Fourthly, it is the formation of transethnical nation on the basis of common public interests and ideological values (an ideological nation). On the basis of this nation, the national ideological identity is formed.

Currently, the discourses about the nation in Russia are held at two levels-the theoretical reflection on questions about whether the Russian nation exists and what its characteristics are, and political projects conceptualizing, associated with the formation of the Russian people as a nation. At the level of theoretical reflection on questions about whether Russia is a nation, there are various opinions expressed. Some researchers believe that the macro political community behind the Russian State, is difficult to fit into the idea of the nation in the construction of national identity, providing national integration. This is due to the fact that the macro-political identity construction occurs in the postimperial context which implies, on the one hand, a competition of "nation-building" projects and, on the other hand, the presence of political and cultural resources to construct this identity in a supranational system of coordinates (Malinova, 2012). Therefore, in modern Russia, apparently, there is neither multi-ethnic nation nor trans-ethnic nation.

Other researchers believe that there is a nation in Russia, but how to call it-a civil nation or a political nationthat's an uneasy issue. In particular, some researchers believe that "the process of a civil nation forming has been going in Russia for a long time and successfully enough, and in some sense or at some event moments one should speak about the Russian nation as a fact accompli of public conscience" (Tishkov, 2011). Yet others speak only about the possibility of a civil nation emergence in the near future, correlating this process with practices of civil society developing in Russia (Gorshkov, 2011).

Thus, modern discursive practices in Russia produce such different models of national identity, proposed as possible individuals' identity matrices, constituting the nation as an imagined community. Probably, such kinds of national identity, in order to avoid terminological confusion, one should better call the national-state and national civil ones. The results of the sociological research show that in the Russian society the national-state identity dominates, it implies loyalty to the state, its history and standards, as well as the feelings about them. Thus, according to public opinion polls, $95 \%$ of respondents identified themselves as "citizens of Russia", while $72 \%$ felt their commonality with the citizens of Russia "to a significant extent". This proved to be the strongest identity among other most important identities. However, there are also elements of national civil identity, including views and a sense of community with the country citizens, a feeling of solidarity with them, responsibility for one's own future and the lives of others. In general, however, national identity in Russia keeps a painful experience of changes, negativity of phobias and feelings (Drobizheva, 2013).

In particular, when respondents were asked a qualifying question: "whom do you feel more?", it turned out that in Russia, 47\% consider themselves "rather Russians", 25\% equally feel "Russians" and representatives of their own (different) nationality. The Russians referred to themselves as "rather Russians" a little more often than people of other nationalities (48\% vs. 39\%). In the republics, among the titular nationalities, the respondents considered themselves primarily to be representatives of their nationality (Drobizheva, 2012).

All this suggests that Russia has developed a political nation and formed the national-state identity as one of the models of national integration, which, however, faces strong competition from the ethno-national identity, defined as the individuals' identity which make up the ethnic community, seeking to strengthen its statehood. It is for this reason that the current national-state identity as national integration model has been insufficient to overcome the interethnic and interfaith contradictions, and therefore it turned out to be unable to become the real basis of national integration (Avksentiev, Aksyumov, 2013).

Thus, the formed national-state identity did not become a factor of consolidating a multi-ethnic Russian society and its national integration. In this regard, in modern Russia they started to search for a new trans-ethnical identity matrix as the foundation of national identity and a national integration model. Currently, such a search is being conducted in line with the identification of Russia as a local civilization, based on which the formation of a national-civilizational identity becomes possible, capable of providing the national integration of the multi-ethnic Russian community.

National-civilizational identity is the imaginary collective identity. It is "imaginary" not in the sense that it does not exist as a social reality, but that it is the result of an individual's self-identification with civilization as an imagined community. The national-civilizational identity is the result both of informational impact (constructivist efforts), and of cultural actualization (essentialist prerequisites). The possibilities of information impact appear due to the fact that different images of Russia as a civilization are created in the discourse, while the actors, possessing the symbolic capital of authority, impose these images onto the public consciousness as possible identity matrices. However, the matrices become the basis for the individuals' identification, making up civilization as an imagined community, provided that these matrices correspond to the human mental program. Because of this, civilizational identities, on the one hand, become the 
projection of individuals' conscious views about the civilization they belong to, and on the other hand, the projection of subconscious civilizational archetypes, or cultural codes.

Currently, the discourse has developed different civilizational images of Russia. First of all, these are the images of Russia as an Eastern-Christian, Orthodox, Russian, Russian-Slavic, or East Slavic, Eurasian and Russian civilization. The images of Orthodox, Rus' and Russian civilization are possible identity matrices as a basis for the nationalcivilizational identities formation in Russia. However, since the identity matrix shall be the basis of the national civilization identity formation of a trans-ethnical and over-confessional nature, the most suitable for this purpose is the image of Russia as the Russian civilization.

Projects related to the national-civilizational identity formation in Russia, are greeted with criticism from liberalminded discursive practices' participants. Some of them, overemphasizing Western patterns of forming civil society in Russia and civil identity, consider attempts to use the idea of civilization as an alternative to the nation invalid, seeing them as an attempt to hide the "odious empire" with its vertical organization behind a respectable term a "special civilization". In addition, the discourse on civilization and civilizational identity in Russia is seen as a resuscitation of its ideological seme "special path."

In this connection, attention is drawn to the fact that within the methodology of the new universalism, the understanding of local civilizations in the age of globalization has changed significantly.

The representatives of this methodology suggested a synthetic concept of local civilizations in terms of their global interaction, taking into account the trend towards globalization and the trend towards localization. Recognizing the existence of a global configuration of universal symbolic forms, they begin to apply the concept of "civilization" only to socio-cultural entities which have the creative ability to produce (or recycle) universal symbols, i.e. which have the character for communication, mastering and interpreting universal idioms and meanings. It is emphasized that certain civilizations produce their own assessments of these universals and express them through the prism of their values and historical experience. In this regard, local civilizations can be seen as "challenges" to the global imperatives, while civilizational identities as the basis of the civilizations' reproduction in the international politics (Hall \& Jackson, 207). Such a communicative-hermeneutical interpretation of local civilizations overcomes the idea of them as of discrete sociocultural units.

In this regard, the discourse on national-civilization identity in Russia is not an attempt to justify its specific path ideologically in the confrontation with the West, but the desire to form their own, explained with its civilizational specificity "answers" to the "challenges" of globalization as a factor of consolidating the Russian society and a prerequisite for the national integration.

\section{Conclusion}

Discourses on national and cultural identities in Russia produce different identification matrices for individuals constituting such imagined communities, as nation and civilization. National and civilizational identities are the varieties of a collective identity, which is formed as a result of informational influence and cultural actualization. In relation to Russia one should distinguish between a national-state identity, evolving on the basis of the political nation, consisting of the Russian Federation citizens, and a national civic identity, emerging on the basis of a civil nation as a civic community. Currently, Russia has developed a political nation and formed a national-state identity, which, however, is experiencing strong competition with the ethno-national identity. Therefore, the national-state identity as the basis for one of the models of national integration proved insufficient for overcoming inter-ethnic contradictions in Russia and consolidating the Russian society.

In this connection, a search has begun for another integrational identity and a national integration model, capable of overcoming the disintegrational potential of ethnic and ethno-confessional differences in the Russian society. A national civilized identity, formed on the basis of the image of Russia as the local civilization can become such an identity. The difficulties of forming a national-civilizational identity as one of the models of national integration are explained, on the one hand, by the existence of different civilizational images of Russia in the discourse and, on the other hand, by the fact that civilization identity matrix is currently located on the periphery of the mass consciousness in the Russian society. Therefore, a special role in its construction is played by sociocultural and institutional practices.

\section{Acknowledgements}

This article was financially supported by the internal grant from the Southern Federal University No. 213.01-072014/15ПЧВГ "Threats to the national security in the face of geopolitical competition and models of aggressive and hostile behavior of young people". 


\section{References}

Anderson, B. (1983) Imagined Communities: Reflections on the Origin and Spread of Nationalism. London: Verso.

Barkov, F.A., Lubsky, A.V., Lubsky, R.A. (2013) Transformation of Intellectual Discourse on Collective Identities // Middle-East Journal of Scientific Research. № 17 (10). P. 1425-1428.

Bell, D.S.A. (2003) Mythscapes: memory, mythology and national identity // The British Journal of Sociology. Vol. 54. No 1. P. 63-81.

Brubaker, R., Beyond, C. F. (2000) «ldentity» // Theory and Society. Dordrecht. Vol. 29. No 1. P. 1-47.

Roniger, L. \& Sznajder, M. (ed) (1998) Constructive collective identities and shaping public spheres: Latin American paths. Brighton; Sussex Academic Press. P. 103-143.

Goldschmidt, P. (2010) Europe's Identity Crisis // The New York Times, February 5.

Greenfeld, L., Eastwood, J. (2007) National Identity // The Oxford Handbook of Comparative Politics / Ed. by C. Boix, S.C. Stokes. Oxford university press. P. 256.

Hall, M. \& Jackson, P.T. (ed) (2007) Civilizational Identity. The Production and Reproduction of «Civilizations» in International Relations I Ed. by. New York: Palgrave Mcmillan.

Huntington, S. (2004) Who Are We? The Challenges to America's National Identity. New York: Simon \& Schuster.

Karolewski, I. (2010) Citizenship and Collective Identity in Europe. London; New York: Routledge. P. 24-43.

Martin, D.-C. (1995) The choices of identity // Social identities. Basingstoke. Vol.1.N1.P. 5.

Robertson, R. (1995) Glocalization: Time-Space and Homogeneity-Heterogeneity // Global Modernities. Ed. by M. Featherstone, S. Lash, R. Robertson. London.

Robertson, R., Knondker, H. (1999) Discourses of globalization: Preliminary considerations // International Sociaology. Vol.13. No 1. P. $25-40$.

Zevelev, I. (2009) Russia's Future: Nation or Civilization? // Russia in Global Affairs. URL: http:// www.eng.globalaffairs.ru/number/n_ 14246

Avksentyev, V.A., Aksyumov, B. V.(2013) Rossiyane: ot grazhdanskoy k tsivilizatsionnoy identichnosti // Nauchnaya mysl' Kavkaza. № 4. P. 32-35. [in Russian]

Velikiye imitatory: Vladislav Inozemtsev o posledstviyzkh voobrazhaemoy mobilizatsii obtschestva // Gazeta.Ru. URL: http://www.gazeta. ru/comments/2015/04/03_a_6624321.shtml [in Russian]

Gorshkov, M.K. (2011) Sotsial'niye osnovy formirovaniya grazhdanskoy natsii v sovremennoy Rossiyi // Fenomen identichnosti v sovremennom gumanitarnom znanii: k 70-letiyu akademika V.A. Tishkova. M.: Nauka. P. 104. [in Russian]

Drobizheva, L.M. (2013) Grazhdanskaya, etnicheskaya I regional'naya identichnost': vchera, segodnya, zavtra. M.: Rossiyskaya poloticheskaya entsiklopediya. P. 7, 39-40, 47-48. [in Russian]

Drobizheva, L.M.. (2012) Rossiyskaya identichnost' i soglasiye v mezhetnicheskikh otnosheniyakh: opyt 20 let reform // Vestnik Rossiyskoy natsii. № 4-5. [in Russian]

Inozemtsev, V.L. (2013) Poteryannoye desyatiletie. M.: Moskovskaya shkola politicheskikh issledobaniy. P. 300-312. [in Russian]

Malinova, O.Y. (2012) Rossiyskaya identichnost' mezhdu ideyami natsii i tsivilizatsii // Vestnik instituta Kennana v Rossii. Issue. 22. P. 48. [in Russian]

Malinova, O.Y. (2010) Simvolicheskaya politika I konstruirovaniye makropoliticheskoy identichnosti v postsovetskoy Rossii // Politicheskie issledovaniya. № 2. P. 93-94. [in Russian]

Tishkov, V.A. (Ed.) (2011) Rossiyskaya natsiya: stanovleniye i etnokul'turnoye mnogoobraziye. M.: Nauka. P. 3-4. [in Russian] 